\begin{tabular}{llllllllllll}
$\mathrm{S}$ & $\mathrm{P}$ & $\mathrm{R}$ & $\mathrm{A}$ & $\mathrm{W}$ & $\mathrm{O}$ & $\mathrm{Z}$ & $\mathrm{D}$ & $\mathrm{A}$ & $\mathrm{N}$ & $\mathrm{I}$ & $\mathrm{A}$ \\
\hline
\end{tabular}

\title{
XIV Ogólnopolskie Sympozjum Prawa Wyznaniowego pt. Prawo wyznaniowe formalne połączone ze Zjazdem Katedr, Zakładów i Wykładowców Prawa Wyznaniowego, Zielona Góra - Kęszyca Leśna, 8-10 maja 2017 r.
}

Zgodnie ze zwyczajem Polskiego Towarzystwa Prawa Wyznaniowego, podczas XIII Ogólnopolskiego Sympozjum połączonego ze Zjazdem Katedr i Wykładowców Prawa Wyznaniowego, zorganizowanego przez Uniwersytet Opolski w Jarnołtówku, dokonano wyboru następnego organizatora. Wybór padł na nowy ośrodek na mapie Wydziałów Prawa i Administracji w Polsce - Uniwersytet Zielonogórski. Ośrodek ten ochoczo podjął się zaszczytnego zadania i rozpoczął rozmowy na temat konkretnego miejsca, a przede wszystkim tematyki obrad.

Dzięki życzliwości Uniwersytetu Zielonogórskiego oraz Diecezji Zielonogórsko-Gorzowskiej udało się pozyskać Aulę Uniwersytecką w budynku Rektoratu UZ oraz Diecezjalny Ośrodek Szkoleniowo-Konferencyjny w Kęszycy Leśnej koło Międzyrzecza. Jak przystało na prawnicze środowisko naukowe - projekt tematyki obrad powstał w drodze z sali sądowej na publiczną obronę rozprawy doktorskiej i pierwotnie brzmiał: „Pozycja podmiotów wyznaniowych w postępowaniach sądowych, administracyjnych i innych". Prof. Mezglewski natychmiast zsyntetyzował go w „Wyznaniowe prawo formalne”. Dalsze, szeroko zakrojone konsultacje nie przyniosły w tym zakresie zmian...

W ten sposób środowisko prawa wyznaniowego spotkało się na swoim dorocznym Zjeździe w Zielonej Górze i okolicach w dniach od 8 do 10 maja 2017 roku. 
Pierwsza sesja, otwierająca Zjazd miała miejsce w Auli Rektoratu Uniwersytetu Zielonogórskiego. Uroczystego otwarcia dokonali: Prorektor UZ prof. dr hab. Wojciech Strzyżewski, prodziekan WPiA UZ dr Robert Wysocki, Prezes PTPW prof. UO dr hab. Paweł Sobczyk oraz organizator - prof. UZ dr hab. Tadeusz Stanisławski. W części naukowej sesji inauguracyjnej wystąpili: prof. AJP dr hab. Paweł Leszczyński (20 lat sformułowań prawnowyznaniowych Konstytucji RP - między stabilnościa a potrzeba korekty), prof. dr hab. Artur Mezglewski (Mechanizmy kontroli przetwarzania danych osobowych członków związków wyznaniowych o uregulowanej sytuacji prawnej), prof. dr hab. Tadeusz J. Zieliński (Austriackie prawo o islamie z 2015 roku - proces stanowienia i główne unormowania) oraz prof. UKSW dr hab. Jan Krajczyński (Wolność sumienia $i$ religii a dochodzenie $i$ obrona uprawnień $w$ kościelnych procesach matżeńskich). Po dyskusji oraz zwiedzeniu centrum Zielonej Góry uczestnicy zjazdu przemieścili się do Kęszycy Leśnej.

Drugi dzień obrad zaczął się od godz. 9.00 a prelegenci spotkali się na czterech równoległych sesjach tematycznych. W pierwszej z nich (Formalnoprawne gwarancje wolności sumienia i religii) głos zabrali: dr Marcin Olszówka (Proceduralne aspekty korzystania z klauzuli sumienia), $\mathrm{dr}$ hab. Wojciech Brzozowski (Przekonania religijne sędziego a instytucja wytaczenia sędziego), prof. UR dr hab. Piotr Steczkowski (Tajemnica zawodowa duchownego), mgr Michał Ożóg (Informacja o wyznaniu pacjenta $w$ kontekście prawa do opieki duszpasterskiej $w$ podmiotach leczniczych $w$ Polsce - zagadnienia wybrane), dr Bartłomiej Pieron (Organizacja zgromadzeń przez członków kościołów i innych związów wyznaniowych), dr Michał Zawiślak (Procedura dotyczaca prawnokarnej ochrony wolności religijnej w wybranych państwach europejskich), prof. UWr dr hab. Józef Koredczuk (Specyfika postępowania dowodowego w przypadku przestęsstw przeciwko wolności sumienia $i$ wyznania na podstawie Kodeksu postępowania karnego z 1997 r.) oraz prof. UO dr. hab. Andrzej Szymański (Inwigilacja kadry i alumnów Wyższego Seminarium Duchownego we Wrocławiu przez Urzad Bezpieczeństwa Publicznego w latach 1953-1954).

$\mathrm{W}$ drugiej sesji równoległej (Wyznaniowe osoby prawne $w$ obrocie prawnym) wygłoszono referaty: dra hab. Marka Bieleckiego (Przetwarzanie danych osobowych przez zwiąek wyznaniowy ,Świadkowie Jehowy w Polsce"), dra Michała Hucała (Ochrona danych osobowych w kontekście wybranych Kościołów mniejszościowych w Polsce-aspekty formal- 
noprawne), prof. UO dra hab. Dariusza Walencika (Kuria diecezjalna jako uczestnik obrotu prawnego), dra Michała Skwarzyńskiego (Wniosek $i$ skarga zwiazku wyznaniowego do Trybunatu Konstytucyjnego, jako dwa środki formalnoprawne inicjowania postępowania), dra Michała Poniatowskiego (Skarga kościelnej osoby prawnej na decyzję w postępowaniu sadowoadministracyjnym), dr hab. Anny Tuni (Procedura ustalania wykazu podmiotów urzędowych zawarcia matżeństwa cywilnego w formie wyznaniowej), dra Michała Chajdy (Kredytowanie kościelnych osób prawnych), mgra Marka Paszkowskiego (Wpis sakralnego obiektu do rejestru zabytków) oraz dra Marka Strzały (Struktura statutu związku wyznaniowego).

W trzeciej sesji równoległej (Postępowania wewnątrzkościelne) można było wysłuchać wystąpień: prof. dra hab. Wojciecha Góralskiego (Kanoniczny proces matżeński skrócony przed biskupem - nadzieje i obawy), mgr Edyty Włodarczyk (Procedura zawarcia związu małżeńskiego w Kościele Ewangelicko-Augsburskim), mgra Rafała Kaczmarczyka (Formalnoprawne aspekty zawarcia i rozwiązania matżeństwa muzulmanów w Polsce do 1946 r.), mgra Tomasza Reslera (Procedura zawarcia zwiazku małzeńskiego u Karaimów w okresie II RP), dr Justyny Krzywkowskiej (Nowelizacja Kodeksu Prawa Kanonicznego wyrazem troski o wiernych. Rozważania na przykładzie „Mitis Iudex Dominus Iesus”), prof. UWM dra hab. Mieczysława Różańskiego (Księgi metrykalne Kościoła Katolickiego. Analiza historyczno-prawna), dra Dariusza Mazurkiewicza (Postępowanie w przypadkach oskarżeń duchownych o wykorzystywanie seksualne osób małoletnich w Kościele Katolickim w Polsce).

W czwartej sesji wyniki swoich badań przedstawiali zielonogórscy administratywiści i konstytucjonaliści: dr Piotr Kapusta, dr Ewa Żołnierczyk, dr Justyna Michalska - sesji tej przewodniczył organizator prof. UZ dr hab. Tadeusz Stanisławski.

Po południu uczestnicy Zjazdu mieli okazję zwiedzić okoliczną część Ziemi Lubuskiej: Międzyrzecki Rejon Umocniony, Pocysterski Zespół Klasztorny w Paradyżu - siedzibę Wyższego Seminarium Duchownego Diecezji Zielonogórsko-Gorzowskiej, a od niedawna Pomnik Historii oraz Sanktuarium Maryjne w Rokitnie.

Wieczorem odbyło się posiedzenie Zarządu oraz Walne Zgromadzenie Członków Polskiego Towarzystwa Prawa Wyznaniowego.

Na zwyczajowej uroczystej kolacji do uczestników Zjazdu dołączył Dziekan WPiA UZ prof. dr hab. Bogusław Banaszak, prezes zielonogór- 
skiego Samorządowego Kolegium Odwoławczego Robert G. Makarowicz, Ekonom Diecezji Wojciech Jurek oraz inni zaproszeni Goście.

W ostatnim dniu spotkania polskiego środowiska prawa wyznaniowego odbyła się jedna sesja plenarna (Formalnoprawne aspekty relacji Państwo - Kościót) od godz. 9.00, a swoje przedłożenia w jej ramach zaprezentowali: prof. dr hab. Krzysztof Krasowski (Dyskusje i spory wokót ratyfikacji polskiego konkordatu z 1993 r.), dr Maciej Kubala (Delibacja wyroków sadów kościelnych we włoskim systemie prawnym), mgr Konrad Zamirski (Restytucja mienia Kościoła Anglikańskiego w Polsce przed Międzykościelna Komisja Regulacyjna), prof. UO dr hab. Paweł Sobczyk (Problemy proceduralne $w$ relacjach Państwo - Kościól, wynikajace z postanowień Konkordatu i ich interpretacji), prof. UO dr hab. Jerzy Nikołajew (Organizacja obchodów 1025. rocznicy chrztu Rusi Kijowskiej jako przykład szczególnych relacji Państwo - Kościół na Ukrainie), mgr Michał Czelny (Procedura wystapień z Kościoła Katolickiego w kontekście obowią$k u$ aktualizacji danych osobowych). Później nastąpiło podsumowanie i zamknięcie Zjazdu i Sympozjum dokonane przez Prezesa PTPW.

Oprócz niezaprzeczalnego waloru corocznego spotkania polskiego środowiska prawa wyznaniowego, organizatorzy wyrazili nadzieję na początek nowej jakości w tematyce obrad. Po wielu spotkaniach poświęconych kwestiom materialnym lub historycznym prawa wyznaniowego, po raz pierwszy podjęto wysiłek zmierzający do systematyzacji formalnego prawa wyznaniowego. Niektóre kwestie przewijały się podczas poprzednich zjazdów, sympozjów oraz konferencji, jednak po raz pierwszy w całości obrady poświecono tej tematyce. Poszczególne wystąpienia stały się przyczyną ożywionej debaty naukowej. W powszechnym odczuciu nie wyczerpano całości tematyki i być może powróci ona w kolejnych odsłonach naukowych spotkań wyznaniowych. Zaprezentowane referaty, zgodnie z decyzją Zarządu PTPW, będą publikowane w oficjalnym periodyku Towarzystwa „Przegląd Prawa Wyznaniowego”.

Ks. dr hab. Tadeusz Stanisławski, prof. UZ Wydziat Prawa i Administracji Uniwersytet Zielonogórski 